\title{
Basic ecology of the Oaxacan Spiny-tailed Iguana Ctenosaura oaxacana (Squamata: Iguanidae), in Oaxaca, Mexico
}

\author{
Tamara Rioja ${ }^{1,2}$, Arturo Carrillo-Reyes ${ }^{1,2}$, Eduardo Espinoza-Medinilla ${ }^{1} \&$ \\ Sergio López-Mendoza ${ }^{1}$ \\ 1. Sustentabilidad y Ecología Aplicada, Universidad de Ciencias y Artes de Chiapas, Lib. Norte Pte. No.1150, Lajas \\ Maciel, Tuxtla Gutiérrez, Chiapas, México; tamararioja@gmail.com, eespinoza@unicach.edu.mx, \\ slopez@unicach.edu.mx \\ 2. Oikos: Conservación y Desarrollo Sustentable, A.C., San Cristóbal de las Casas, Chiapas, México; \\ acarrillo@oikos.org.mx
}

Received 04-XI-2011. Corrected 10-V-2012. Accepted 12-VI-2012.

\begin{abstract}
The Oaxacan Spiny-tailed Iguana Ctenosaura oaxacana is a restricted species to the Isthmus of Tehuantepec in Southern Oaxaca, Mexico. This reptile is one of the less known iguanid species. We censustracked a population in the South of Niltepec, Oaxaca, Mexico from May 2010 to April 2011. Throughout one year, a total of 10 line transects were situated and recorded in the study area to determine relative abundance and density, and habitat type use (dry forest, Nanchal, grassland, riparian vegetation, and mangrove) by the species. This study reports a new C. oaxacana population on the Southeastern limit of species range. Although this species has a very restricted distribution and is in danger of extinction, C. oaxacana has a high population density when compared to other Ctenosaura species. A total of 108 individuals were recorded throughout the study. Dry forest (33.75ind/ha) and Nanchal (18.75ind/ha) were the habitats with higher densities. Comparisons between habitat types showed no significant differences between dry forest and Nanchal (W=15, $\mathrm{p}=0.0808)$. Results between seasons were similar. The Oaxacan Spiny tailed Iguana preferred first the dry forest, and then Nanchal, while avoided grassland, riparian vegetation, and mangroves. There was no difference in habitat use between males and females. Mean perch heights were $1.23 \pm 0.32(\mathrm{n}=30)$ in Nanchal, $2.11 \pm 0.30(\mathrm{n}=9)$ in grassland, $1.90 \pm 0.56(\mathrm{n}=54)$ in dry forest, $1.91 \pm 0.28(\mathrm{n}=9)$ in mangrove and $2.30 \pm 0.37(\mathrm{n}=6)$ in riparian vegetation. Species observed as refuge and perch were B. crassifolia (Nanchal); C. alata (grassland); Tabebuia sp., Genipa americana, G. sepium, Acacia sp., Ficus sp. and Haematoxylon sp. (dry forest); G. sepium, Acacia sp. and Guazuma ulmifolia (riparian vegetation); and C. erecta (mangrove). Live trees hollows and branches were used by species. Main threats to the species are excessive hunting and habitat loss. Furthermore, grassland fires are still common in the study area during the dry season, which can result in habitat loss and territorial displacement of individuals. Rev. Biol. Trop. 60 (4): 1613-1619. Epub 2012 December 01.
\end{abstract}

Key words: Ctenosaura oaxacana, habitat use, density, abundance, Isthmus of Tehuantepec, Oaxaca.

The Oaxacan Spiny-tailed Iguana (Ctenosaura oaxacana, Köhler \& Hasbún 2001) named by the local people as "guiou" (in "zapoteco" language), and which prior to 2001 was named as five-keeled Spiny-tailed Iguana (C. quinquecarinata, Gray 1842), is a critically endangered species restricted to the Pacific versant of the Isthmus of Tehuantepec, Oaxaca, Mexico. Species distribution is restricted to less than $100 \mathrm{~km}^{2}$ with six to ten surviving subpopulations highly isolated due to deforestation, frequent habitat burning, and poaching. Total population size is not known, but an occurrence of fewer than 2500 mature individuals is expected on the basis of current habitat conditions, population size which is further expected to decline by at least $30 \%$ over the next 10 years if current rates of habitat loss continue (Köhler \& Hasbun 2001, Köhler 2004). 
Despite their importance, there have been very few studies on the species. Records on $C$. oaxacana are very scarce; and only reported for tropical deciduous forest at altitudes ranging from sea level to $250 \mathrm{~m}$. The only records from Salina Cruz date from 1920 (Köhler \& Hasbun 2001). In 1983, 15 individuals were collected near of Tehuantepec, Municipality of Santo Domingo Tehuantepec (Instituto de Biología 2011); between 1980-1983 four specimens were collected from localities in Santo Domingo Tehuantepec, San Mateo del Mar, and Santa María Chimalapa (Reynoso-Rosales 2007); while Köhler (1995) described some behavioral aspects from populations located in Tehuantepec and Playa Azul, and Casas-Andreu et al. (1996) reported the occurrence of the species in San Mateo del Mar, Municipality of San Mateo del Mar. Later, five individuals were collected in Nizanda, Municipality of Asunción Ixtaltepec, while another two specimens were collected near Niltepec, Municipality of Santiago Niltepec, and six more at the Municipality of Santa María Mixtequilla (Köhler \& Hasbun 2001, Hasbun et al. 2005). Additional records were reported from Cerro Piedra Larga, an isolated mountain massif in Eastern Oaxaca, located $100 \mathrm{~km}$ to the West of the Isthmus of Tehuantepec, a major biogeographic barrier separating the heart of Mexico from Northern Central America (Peterson et al. 2004, Köhler 2004). Recently, Martín-Regalado et al. (2011) recorded the presence of the species close to the Tehuantepec municipality.

Biological information of C. oaxacana is scarce, and with the only available studies from Köhler (1995) and Köhler \& Hasbun (2001). Population dynamics and habitat use are unknown; this information is required in order to develop effective conservation and management strategies. At the present, the species is not protected and do not occur within any official protected area. However, conservation strategies suggested for the species include extensive field surveys to determine local abundance, habitat use, demographic population dynamics, and inferences on population genetic variability (Köhler 2004). In this study, we aimed to update the current distribution of $C$. oaxacana, and determine its population density and habitat use, to provide valuable biological information towards an effective species conservation planning.

\section{MATERIAL AND METHODS}

The study area of approximately $35 \mathrm{~km}^{2}$ is located in the North of Inferior lagoon at the South of the Isthmus of Tehuantepec, Oaxaca $\left(16^{\circ} 22^{\prime} 00^{\prime \prime} \mathrm{N}-94^{\circ} 35^{\prime} 12^{\prime \prime} \mathrm{W}\right.$ and $16^{\circ} 24^{\prime} 10^{\prime \prime}$ $\left.\mathrm{N}-94^{\circ} 34^{\prime} 47^{\prime \prime} \mathrm{W}\right)$, which is also near to the Montecillo Santa Cruz community, Municipality of San Francisco del Mar. This region is located Northeast of the Istmica-Chiapaneca coastal plain, which is situated between Sierra Madre de Chiapas and Pacific Ocean (Zizumbo \& Colunga 1982).

Climate is tropical with mean annual temperature of $27.6^{\circ} \mathrm{C}$, mean annual rainfall of $800 \mathrm{~mm}$ (INEGI 1995), and with clearly defined seasons. The rainy season occurs from May to October with an intra-estival drought in August, while the dry season occurs from November to April, particularly drastic weather conditions occurs during late winter and early spring (Zizumbo \& Colunga 1982).

Montecillo Santa Cruz presents five habitat types: 1- Grassland: open and plain areas, flooding during wet season, and characterized by a forb stratum of grasses, herbs, scattered isolated "morro" trees (Crescentia alata Kunth 1819), and shrubs. The most frequent plants are grass species such as Aristida sp. and Trisetum sp. 2- Nanchal: semi open areas of mainly forbs and shrubs strata; shrubs density is higher than grassland and the dominant species is the "Nanche" or Byrsonima crassifolia (L.) Kunth (1822), a common species form SouthSoutheast Mexico. 3- Dry forest: close areas of thorny and deciduous shrubs, and trees up to four meters high. The most frequent species are Acacia farnesiana (L.) Willd. (1806), Casearia sp., and Aristida sp. 4- Riparian vegetation: little patches of dense vegetation growing in stream margins; and characterized by very high deciduous trees (15m height). Aristida sp., 
Gliricidia sepium (Jacq.) and Celtis iguanaea (Jacq.) Sarg. are the characteristic species. 5- Mangrove: characterized by two species, Rhizophora mangle L. (1753) and Conocarpus erecta L. (Farías 2004, Sántiz 2005, Lorenzo et al. 2008). No rocky terrain occurs at any surveyed habitat types (Pérez-García et al. 2001).

Local people from Montecillo Santa Cruz are traditional fishermen, although in the last years agriculture has become the most important productive activity of basic food products. Other activities such as commercial trade, cattle raising, and hunting are of minor economic importance (Vargas-Espíndola 2001). Extensive cattle raising is carried out in the whole zone of the grassland, and burning practices are common to promote grass regeneration (Lorenzo et al. 2008).

Monitoring: Data were obtained from four field surveys of eight days (from 09001 500h), from May 2010 to April 2011, and during the dry and rainy seasons. Two lineal transects of a total length of $500 \mathrm{~m}$ and variable width each based on distance sampling proposed by Thomas et al. (2010), were evaluated per vegetation type. Transects were located randomly per vegetation type, with at least $500 \mathrm{~m}$ separating them. Each transect was visited once a day by two persons; we visually inspected the branches of the trees and recorded the occurrence of every Oaxacan Spiny-tailed Iguana. The perpendicular distance from the line of each individual sighted was registered. Additionally, every tree and ground hole along each transect was checked, as they were used as hideouts by the species. Other observations included: sexual activity, behavior at sight moment, perch height and plant species used by C. oaxacana. Geographical coordinates (eTrex Vista, 3-15m precision, Garmin, Kansas) of each observed individual was recorded. Seasonal and annual relative abundance and mean density were obtained using Distance v.6. (Thomas et al. 2010). Comparison of relative abundance between habitat types was analyzed by a non-parametric Wilcoxon test (Motulsky 1995).
Whenever possible, we took high-quality photographs of the specimens observed. The photographs were added to the Image Database of the National Commission for Knowledge and Use of Biodiversity (Banco de Imágenes, Comisión Nacional para el Conocimiento y Uso de la Biodiversidad, https://conabioweb. conabio.gob.mx/fotoweb/) and were donated to the media initiative ARKive-images on life on earth (http://www.arkive.org/).

Habitat use data were analyzed using chisquare $\left(\chi^{2}\right)$ test to assess significant differences in habitat use by $C$. oaxacana and the expected occurrence based on the availability of each type of habitat in the area. Bonferroni intervals were applied for each statistical significant difference observed to determine whether or not selection of habitat type existed (Neu et al. 1974, Byers et al. 1984).

\section{RESULTS}

New records of $C$. oaxacana were reported for the North border of the Inferior lagoon, in the Southeastern region of Isthmus of Tehuantepec. A total of 108 individuals were recorded throughout the study, in which 104 records correspond to single individuals, whereas three records correspond to couples (male-female). We recorded one case of three individuals (male-female-female) occurring in the same tree branch.

Highest relative abundance and density were estimated for dry forest, and followed by Nanchal (Table 1). Comparisons between habitat types showed no significant differences between dry forest and Nanchal $(\mathrm{W}=15$, $\mathrm{p}=0.0808$ ), and neither between habitat types showing the lowest values such as comparison between riparian vs. grassland and riparian vs. mangrove ( $\mathrm{W}=39, \mathrm{p}=0.4674)$. Differences between seasons had similar results. In regard to rainy season and dry season, dry forest and Nanchal were the habitat types which showed highest values on relative abundance and density for both rainy and dry seasons.

Habitat use analysis showed that $C$. oaxacana preferred dry forest, followed by 
TABLE 1

Relative abundance and density estimation for C. oaxacana per habitat type in Montecillo Santa Cruz, Oaxaca

CUADRO 1

Estimación de la abundancia relativa y la densidad de C. oaxacana por tipo de hábitat en Montecillo Santa Cruz, Oaxaca

\begin{tabular}{|c|c|c|c|c|c|c|c|c|}
\hline \multirow{2}{*}{ Habitat type } & \multicolumn{3}{|c|}{ Relative abundance } & \multicolumn{3}{|c|}{ Density (ind/ha) } & \multirow{2}{*}{ d.f. } & \multirow{2}{*}{$\mathrm{p}$} \\
\hline & Mean & $\mathrm{SD}$ & CI & Mean & $\mathrm{SD}$ & $\mathrm{CI}$ & & \\
\hline Nanchal & 0.01 & 0.00 & $0.0057-0.0266$ & 18.75 & 6.40 & $6.1889-31.3110$ & 7 & $<0.05$ \\
\hline Grassland & 0.00 & 0.00 & $0.0010-0.0055$ & 5.62 & 4.17 & $2.5533-13.8033$ & 7 & $<0.05$ \\
\hline Dry forest & 0.01 & 0.01 & $0.0140-0.0530$ & 33.75 & 12.46 & $9.3201-58.1799$ & 7 & $<0.05$ \\
\hline Mangrove & 0.00 & 0.00 & $0.0010-0.0055$ & 5.62 & 4.17 & $2.5533-13.8033$ & 7 & $<0.05$ \\
\hline Riparian & 0.00 & 0.00 & $0.0097-0.167$ & 3.75 & 3.53 & $3.1796-10.6796$ & 7 & $<0.05$ \\
\hline
\end{tabular}

SD: standard deviation; CI: confidence interval; d.f.: degrees of freedom; ind/ha: individuals per hectare.

TABLE 2

Habitat use by C. oaxacana in Montecillo Santa Cruz population

CUADRO 2

Uso de hábitat de C. oaxacana para la población de Montecillo Santa Cruz

\begin{tabular}{lcccccc} 
Habitat type & EU\% & OU\% & CI & Preference & d.f. & p \\
Nanchal & 0.16 & 0.28 & $0.2413-0.3143$ & Prefer & 4 & $<0.05$ \\
Grassland & 0.59 & 0.08 & $0.0608-0.1058$ & Avoid & 4 & $<0.05$ \\
Dry forest & 0.06 & 0.50 & $0.4593-0.5407$ & Prefer & 4 & $>0.05$ \\
Mangrove & 0.06 & 0.08 & $0.0608-0.1058$ & Prefer & 4 & $<0.05$ \\
Riparian & 0.11 & 0.06 & $0.0369-0.0743$ & Avoid & 4 & $<0.05$ \\
\hline
\end{tabular}

EU\%: proportion of expected resource use; OU\%: proportion of observed resource use; CI: confidence interval; d.f.: degrees of freedom.

Nanchal and mangrove, whereas they avoided grassland and riparian vegetation (Table 2). There was no difference in habitat use between males and females.

Mean perch heights were $1.23 \pm 0.32$ $(\mathrm{n}=30)$ in Nanchal, $2.11 \pm 0.30(\mathrm{n}=9)$ in grassland, $1.90 \pm 0.56(\mathrm{n}=54)$ in dry forest, $1.91 \pm 0.28$ $(n=9)$ in mangrove and $2.3 \pm 0.37(n=6)$ in riparian vegetation. At Nanchal, the $B$. crassifolia shrub was the only species observed as refuge and perch, while at the grassland the C. alata tree was the preferred refuge and perch species observed. At dry forest $C$. oaxacana used Tabebuia sp., Genipa americana (Linneaus 1759), G. sepium, Acacia sp., Ficus sp. and Haematoxylon sp. as refuge and perch. We registered one case in which an individual was observed occurring in a ground hole, but we cannot determine if it corresponded to a common refuge or just a place to escape from observers. At the riparian vegetation G. sepium, Acacia sp. and Guazuma ulmifolia Lam (1789) were the vegetation species used as perch and refuge. At mangrove, $C$. erecta was the only species used as refuge, but we observed an individual perching on $R$. mangle branches. In all cases live trees hollows and branches were used by the species.

\section{DISCUSSION}

On the basis of available information on species distribution, this study reports a new C. oaxacana population in the Southeastern 
limit of the species range (Köhler \& Hasbun 2001, Köhler 2004). However, more surveys are needed, in particular to the Southeast of the study area, where local people say they have seen the occurrence of the species. Additional sites to the East of the Isthmus of Tehuantepec, near the border of the state of Chiapas (CONABIO 1999), characterized by dry forest should also be surveyed. Moreover, is necessary to extensively survey the area between our new records and the former reported populations in Niltepec. These areas are separated by $20 \mathrm{~km}$, thus occurrence of in-between populations might link these known disjoint populations.

Up to date, there is no empirical data on relative density and abundance for any reported population of the species. The little information available has been indicated by Köhler (1995) and Köhler \& Hasbun (2001). Density data for the most closely related species, C. quinquecarinata, on a wildlife refuge in Nicaragua estimated 28 individuals, with a density of $0.93 \mathrm{ind} /$ ha (Robleto 2010); which is a density value very low compared with our results. About other species, Teran (2006) reported a maximum value of $3.1 \mathrm{ind} / \mathrm{ha}$ in Honduras (C. similis), while Zurita-Carmona et al. (2009) reported a maximum value of $1.01 \mathrm{ind} /$ ha in Mexico (C. pectinata). In both cases, the population density was less than $C$. oaxacana density. Although the population density of C. oaxacana seems high when compared with other species, it is significant to note that this species has a restricted distribution in Southern Oaxaca, Mexico. Additionally, we know that $C$. oaxacana have a specific preference to dry forest.

In the dry forest habitat, $C$. oaxacana density reached values of $33.75 \mathrm{ind} / \mathrm{ha}$. However, the preferred habitat (dry forest) is not the most abundant habitat type. Villa \& Scott (1967) reported that $C$. quinquecarinata prefers dry forest trees and roots, while Robleto (2010) reported the greatest number of specimens recorded in the scrub and dry forest. Also, consistently with our results Villa \& Scott (1967) and Robleto (2010) reported riparian vegetation as an avoided habitat. Vegetal species used in the preferred habitat types might provide enough quantity and quality of habitat for the species. Particularly, existence of holes in logs allows the species to shelter from weather and potential predators.

Although Köhler (1995) recorded a single individual per tree in its report, during our census-tracks we recorded three couples (malefemale) and a group of two females and one male. However, due to the design of our census-tracking, we could not determine whether this observed pattern was due to reproductive or social behavior, or was a random episode as a result of our presence when we approach them. Despite being the second documented record, it is a priority to collect more behavioral data on the species (Kohler 2004).

As Köhler \& Hasbun (2001) reported, excessive hunting by local people, coupled with habitat loss are the major threats of $C$. oaxacana, but local people reported that the species is slightly hunted because is too small to be an important source of food (CarrilloReyes, pers. comm.). Similarly, Robleto (2010) in Nicaragua, were C. quinquecarinata densities was lower than C. oaxacana, reported the same major threats. Furthermore, grassland fires during the dry season are common in the study area, which can results in habitat loss and territorial displacement of individuals. As well, high degree of habitat loss and fragmentation in the study area (Carrillo-Reyes, pers. comm.) might affect both the distribution and density of the species. Further studies are needed concerning issues such as reproduction, diet, and behavior of $C$. oaxacana in Mexico.

\section{ACKNOWLEDGMENTS}

We thank the municipal and communal authorities of Montecillo Santa Cruz and San Francisco del Mar, Oaxaca, especially to all local families. We are grateful to the students from UNICACH and UJED for their help during the fieldwork. We thank the financial support from Programa de Mejoramiento del Profesorado (PROMEP). We thank Y. Rico 
and anonymous reviewers for their comments and suggestions that greatly improved the manuscript.

\section{RESUMEN}

La Iguana de Cola Espinosa Ctenosaura oaxacana es una especie restringida al Istmo de Tehuantepec en el Sureste de Oaxaca, México. Este reptil es uno de los iguánidos menos conocidos. Entre Mayo 2010 y Abril 2011 hicimos el seguimiento de una población al Sur de Niltepec, Oaxaca, México. A lo largo de un año, se colocaron y monitorearon un total de diez transectos en el área de estudio, para determinar la abundancia relativa, densidad y uso de hábitat (selva seca, Nanchal, pastizal, vegetación riparia y manglar) de la especie. Esta investigación reporta una nueva población de C. oaxacana en el límite sureste de la distribución conocida para la especie. Aunque esta especie posee una distribución muy restringida y se encuentra en peligro de extinción, C. oaxacana presenta una alta densidad poblacional comparada con otras especies de Ctenosaura. Se registró un total de 108 individuos a lo largo del estudio. La selva seca (33.75ind/ha) y el Nanchal (18.75ind/ha) fueron los hábitats con densidad más alta. No se encontró diferencia significativa entre la selva seca y el Nanchal $(\mathrm{W}=15, \mathrm{p}=0.0808)$. Al comparar entre estaciones el resultado fue similar. La Iguana de Cola Espinosa prefirió la selva seca y después al Nanchal, mientras que evitó el pastizal, la vegetación riparia y el manglar. No se registró diferencia en el uso de hábitat entre machos y hembras. La altura media de las perchas fue $1.23 \pm 0.32(n=30)$ en Nanchal, $2.11 \pm 0.30(\mathrm{n}=9)$ en pastizal, $1.90 \pm 0.56(\mathrm{n}=54)$ en selva baja, $1.91 \pm 0.28(\mathrm{n}=9)$ en manglar y $2.30 \pm 0.37$ $(n=6)$ en vegetación riparia. Las especies observadas como refugio y percha fueron $B$. crassifolia (Nanchal); C. alata (pastizal); Tabebuia sp., Genipa americana, G. sepium, Acacia sp., Ficus sp. y Haematoxylon sp. (selva seca); G. sepium, Acacia sp. y Guazuma ulmifolia (vegetación riparia); y C. erecta (manglar). La especie utilizó agujeros y ramas de árboles vivos. Las principales amenazas para la especie son la cacería excesiva y la pérdida de hábitat. Además, la quema de pastizales sigue siendo común en el área de estudio durante la temporada seca, lo que puede resultar en la pérdida de hábitat y el desplazamiento territorial de los individuos.

Palabras clave: Ctenosaura oaxacana, uso de hábitat, abundancia, densidad, Oaxaca.

\section{REFERENCES}

Byers, C.R., R.K. Steinhorst \& P.R. Krausman. 1984. Clarification of a technique for analysis of utilizationavailability data. J. Wildl. Manag. 48: 1050-1052.
Casas-Andreu, G., F.R. Méndez De La Cruz \& J.L. Camarillo. 1996. Anfibios y Reptiles de Oaxaca, lista, distribución y conservación. Acta Zool. Mex. (n.s.) 69: 1-35.

CONABIO. 1999. Uso de suelo y vegetación modificado por CONABIO. Catálogo de metadatos geográficos. Comisión Nacional para el Conocimiento y Uso de la Biodiversidad. México, D.F., México.

Farías, V. 2004. Spatio-temporal ecology and habitat selection of the critically endangered tropical hare (Lepus flavigularis) in Oaxaca, Mexico. Ph.D. Thesis, Massachusetts University, Massachusetts, USA.

Hasbun, C.R., A. Gómez, G. Köhler \& D.H. Lunt. 2005. Mitochondrial DNA phylogeography of the Mesoamerican Spiny-tailed lizards (Ctenosaura quinquecarinata complex): historical biogeography, species status and conservation. Mol. Ecol. 14: 3095-3107.

INEGI. 1995. Marco geoestadístico. Dirección General de Geografía del Territorio Nacional, México D.F., México.

Instituto de Biología. 2011. Ctenosaura quinquecarinatusIBUNAM:CNAR:AR5513. UNIBIO: Colecciones Biológicas. Universidad Nacional Autónoma de México, D.F., México. (February 24 2011, http:// unibio.unam.mx/collections/specimens/urn/ IBUNAM:CNAR:AR5513).

Köhler, G. 1995. Freilanduntersuchungen zur Morphologie und Lebensweise des Fünfkiel-Schwarzleguans Ctenosaura quinquecarinata am Isthmus von Tehuantepec, Mexiko. Herpetofauna 17: 21-26.

Köhler, G. \& C.R. Hasbun. 2001. A new species of Spiny-tailed Iguana from Mexico formerly referred to Ctenosaura quinquecarinata (Gray, 1842) (Reptilia, Squamata, Iguanidae). Senckenberg Biol. 81: 257-267.

Köhler, G. 2004. Ctenosaura oaxacana. IUCN Red List of Threatened Species. Version 2010.4. International Union for Conservation of Nature and Natural Resources. Gland, Switzerland and Cambridge, United Kingdom. (January 17 2011, http://www.iucnredlist. org/apps/redlist/details/44190/0).

Lorenzo, C., T. Rioja, A. Carrillo \& F.A. Cervantes. 2008. Population fluctuations of Lepus flavigularis (Lagomorpha:Leporidae) at Tehuantepec isthmus, Oaxaca, México. Acta Zool. Mex. (n.s.) 24: 207-220.

Martín-Regalado, C.N., R.M. Gómez-Ugalde \& M.E. Cisneros-Palacios. 2011. Herpetofauna del cerro Guiengola, istmo de Tehuantepec, Oaxaca. Acta Zool. Mex. (n.s.) 27:359-376.

Motulsky, H. 1995. Intuitive biostatistics. Oxford University, New York, USA.

Neu, C.W., C.R. Byers \& B. Peek. 1974. A technique for analysis of utilization-availability data. J. Wildl. Manag. 38: 541-545. 
Pérez-García, E., J. Meave \& C. Gallardo. 2001. Vegetación y flora de la región de Nizanda, Istmo de Tehuantepec, Oaxaca, México. Acta Bot. Mex. 56: $19-88$.

Peterson, A.T., L. Canseco Márquez, J.L. Contreras Jiménez, G. Escalona-Segura, O. Flores-Villela, J. GarcíaLópez, B. Hernández-Baños, C.A. Jiménez-Ruiz, L. León-Paniagua, S. Mendoza-Amaro, A.G. NavarroSingüeza, V. Sánchez-Cordero \& D. Willard. 2004. A preliminary biological survey of Cerro Piedra Larga, Oaxaca, Mexico: Birds, mammals, reptiles, amphibians, and plants. Ann. Inst. Biol. 75: 439-466.

Reynoso-Rosales, V.H. 2007. Actualización de la base de datos de la colección nacional de anfibios y reptiles (CNAR). Colección Nacional de Anfibios y Reptiles. Instituto de Biología. Bases de datos SNIBCONABIO, proyecto CE006. Universidad Nacional Autónoma de México, México, D.F., México.

Robleto, J. 2010. Estado poblacional de Ctenosaura quinquecarinata en el Refugio de Vida Silvestre Río Escalante-Chacocente. Tesis de Maestría, Universidad Nacional Autónoma de Nicaragua, Managua, Nicaragua.

Sántiz, E. 2005. Selección de hábitat y densidad de la liebre del istmo Lepus flavigularis (Wagner 1844) en Oaxaca, México. Tesis de Maestría, Instituto de Ecología, A.C., Xalapa, Veracruz, México.

Teran-Flores, M.A. 2006. Densidad poblacional del garrobo (Ctenosaura similis) en cuatro habitats del Zamorano y su percepción por la comunidad local. Tesis de Bachillerato, Carrera de Desarrollo Socioeconómico y Ambiente, Zamorano, Honduras.

Thomas, L., S.T. Buckland, E.A. Rexstad, J.L. Laake, S. Strindberg, S.L. Hedley, J.R.B. Bishop, T.A. Marques \& K.P. Burnham. 2010. Distance software: design and analysis of distance sampling surveys for estimating population size. J Appl Ecol 47: 5-14. (Also available on line: http://onlinelibrary.wiley.com/ doi/10.1111/j.1365-2664.2009.01737.x/abstract).

Vargas-Espíndola, Z.F. 2001. Valoración de los vertebrados terrestres por huaves y zapotecas del Istmo de Tehuantepec, Oaxaca, México. Tesis de Maestría, El Colegio de la Frontera Sur, San Cristóbal de las Casas, Chiapas, México.

Villa, R.J. \& N.J. Scott. 1967. The iguanid lizard Enyaliosaurus in Nicaragua. Copeia 2: 474-476.

Zizumbo, D. \& P. Colunga. 1982. Los Huaves. La apropiación de los recursos naturales. Universidad Autónoma Chapingo, Texcoco, Estado de México, México.

Zurita-Carmona, M.E., V.C. Aguilar-Valdez, A. GonzálezEmbarcadero, G.D. Mendoza-Martínez \& J.L. ArcosGarcía. 2009. Composición de la dieta, consume de proteína y energía en la Iguana Negra, Ctenosaura pectinata Wiegmann, 1834, y densidad poblacional en Santos Reyes Nopala, Oaxaca. Univ. Ciencia 25: 103-109. 
